\title{
Analysis of Change in Profitability due to Reinsurance Utilization and Leverage Levels: Evidence from Non-Life Insurance Sector of Pakistan
}

\author{
Hafiza Tahoora Iqbal ${ }^{1}$ \\ Mobeen Ur Rehman ${ }^{2}$ \\ Syed Jawad Hussain Shahzad ${ }^{3}$
}

\begin{abstract}
This paper examines the relationship between profitability, reinsurance and leverage level of private sector non-life stock insurers of Pakistan. The value and significance of reinsurance and leverage levels is analyzed by observing their nature and benefits to the insurer, insurance industry and for financial system as a whole. The study further assesses whether the profitability of the non-life insurance companies dependent on the reinsurance operations and leverage level or not. Secondary data is taken from the annual financial reports of insurance companies over the period of 10 years from 2002-2011. A panel data regression model, Random Effect Model is used which reveals that the profitability is positively related with reinsurance utilization. The leverage levels have a significant negative impact on the profitability. However, the increased dependence on reinsurer decreases the profitability and hence the risk of insolvency may increase. Majority of the insurance companies in order to increase their underwriting capacity and to stabilize their earnings depend a lot on reinsurance and leverage, and this extensive use exposes them to the potential risk of insolvency.
\end{abstract}

Keywords: Leverage level, reinsurance, profitability, reinsurer, Pakistan

\section{Introduction}

Insurance companies underwrite the risk of other companies but to mitigate their own risk, these insurance companies use reinsurance. Reinsurance can be regarded as insurance of the insurer. Insurance covers the external risk of the firms in business and therefore utilizes hedging activities like reinsurance and derivative, so that it can reduce the economical or financial risk resulting due to the imperfections of capital market (Cummins \& Song, 2008). Insurance industry deals with several types of risks such as the risk of terrorism, natural disasters and war with other countries. The nature and magnitude of these risks is such that the insurance companies cannot handle them independently and require an extra ergonomic hedging cover and reinsurance can be treated as such cover for direct insurer. Insurance industry is extremely important for the survival of all the other industries and any problem that could lead to financial distress and losses of insurance industry, is extremely harmful for the whole economy.

Reinsurance can play vital role in risk assessment, risk underwriting and in efficient management of claims. It allows the direct insurer to manage its risk and capital in a well-organized and proficient ways. High and complicated risks can easily be insured by using reinsurance (Baur

\footnotetext{
${ }^{1}$ Hafiza Tahoora is Lecturer, COMSATS Institute of Information Technology, Islamabad, tahoora_iqbal@yahoo.com ${ }^{2}$ Mobeen Ur Rehman is Lecturer, COMSATS Institute of Information Technology, Islamabad, mobeenrehman@live.com

${ }^{3}$ Syed Jawad Hussain Shahzad, Lecturer, COMSATS Institute of Information Technology, Islamabad, jawadhussain@vcomsats.edu.pk

\begin{tabular}{lll|c|c}
\hline JISR-MSSE & Volume 12 & Number 1 & January-June 2014 & 1
\end{tabular}
}


\& Donoghue, 2004). The direct insurer raises its underwriting capacity by using reinsurance. The reinsurer participates in a part of his portfolio and becomes able to write more business and tackle the higher losses accumulated through several contracts, within the solvency requirements. Particularly, the risk funding function is important in cases where the funding requirements are exceptionally high and in case of catastrophic event, it acts as a back up to the insurance market (Archer, Karim, \& Nienhaus, 2009). Reinsurance can be beneficial and can also have negative impact on the industry. Baur and Donoghue (2004), and Cummins, Dionne, and Nouira (2008) have shown that reinsurance can be beneficial as it helps in reducing the regulatory cost and volatility in financial statements and also stabilizes the earnings of the company. On the other hand, the reinsurance arrangement is expensive and can result in insolvency of the direct insurer. This happens when the reinsurer becomes insolvent or when the direct insurer starts writing more and more business without increasing its own capital.

The behavior of insurer affects the insurer's profitability and determines its relationship with reinsurance and leverage level. This study, therefore, analyzes whether the direct insurers are enjoying the benefits of reinsurance arrangement in the shape of increased capacity or they are facing the unconstructive or depressing aspect of such practice in Pakistan. The purpose of this study is to find whether the reinsurance operations and firm's capital structure have any relationship with the profitability of non-life insurance companies. By utilizing the secondary data from 2002-2011 a random effect estimation technique has been applied. Findings suggest that the insurer's profitability is positively related with reinsurance utilization. However, the leverage levels have a significant negative impact on the profitability. Hence, increased dependence on reinsurer decreases the profitability and therefore, the risk of insolvency increases.

\section{Literaute Review}

Cummins and Weiss (2002) have stated that the insurer require reinsurance because it reduces its burden of pure risk. Garven and Tennant (2003) have argued that the reinsurance is used to make sure that the payment of claims in the event of loss and to remain financially solvent. Swiss (2002), Swiss (2003), Garven and Tennant (2003), Baur and Donoghue (2004), Arndt, et al.(2004), Cummins, Dionne, and Nouira (2008), and Pitselis (2008) have stated that the reinsurance practice enhances the capacity of direct insurer and enables it to accept more risks without increasing its own capital while maintaining its solvency requirements. This happens because reinsurance enables the direct insurer to retain fewer losses and require lesser capital as security for losses.

Garven and Tennant (2003), Krvavych and Sherris (2004) and Cole and McCullough (2006) have argued that reinsurance reduces the risk of bankruptcy or insolvency of direct insurer. This risk may increase if the company takes larger risk relative to its capital. However, this risk can also reduce through adequate diversification. The firms with the high probability of bankruptcy have tendency to demand more reinsurance. Chen, Hamwi, and Hudson (2001), Arndt, et al. (2004), Powell and Sommer (2006), and Cummins, Dionne, and Nouira (2008) have stated that reinsurance helps in stabilizing the earnings of direct insurer by increasing its underwriting capacity and by reducing its risk of ruin and bankruptcy. The primary insurers buy reinsurance contracts for twofold purposes, to diversify their risk and to improve their financial stability. But the extensive use of reinsurance may also be due to its financial 
difficulty. The companies in financial difficulty and with higher chances of insolvency tend to use more reinsurance practice due to their inability to raise required capital from financial markets. The availability of reinsurance practice encourages the direct insurer to engage in highly risky business that results in the increased probability of their insolvency. The increase in ceded reinsurance causes the insolvency risk to reduce more due to reduction in the leverage level of the firm. But the continuous increase in ceded reinsurance without increasing the capital may also increase the insolvency risk. This happens because of the unique credit nature of insurance business or due to the obligations that a direct insurer has to its policyholders. The reinsurance practice does not reduce the direct insurer's liability towards its policyholders. The direct insurer is fully liable for making payment to its policyholder whether the reinsurer makes payment or not (Chen, Hamwi, \& Hudson, 2001).

The investment level of direct insurer can be increased by using reinsurance. Firms sometimes give up the valuable opportunities of investment due to the fear of unusual and abnormal losses. Big losses not only trim down the value of the firms but also its equity, resultantly positive net present value (NPV) projects have to be rejected. If the firm procures reinsurance then these unusual losses can be covered or indemnified which in turn allows the firm to accept value increasing project (Mayers \& Smith, 1990). This is an underinvestment problem and Corporate Finance Theory advocates that the companies get themselves insured to resolve this underinvestment problem (Cummins, Dionne, \& Nouira, 2008). The transfer mechanism of reinsurance results in lesser losses and more business without increasing firms capital (Hoerger, A. Sloan, \& Hassan, 1990). Reinsurance is an action for increasing business and for decreasing the probability of losses because this technique allows the insurer to increase its underwriting capacity without increasing its capital (Pitselis, 2008).

Swiss (2003) has investigated that reinsurers can cause a major risk for insurance companies, financial system and for the economy as a whole. There are two major channels through which reinsurer can create systemic risk. These channels include lack of reinsurance coverage and insolvencies of direct insurers and banks triggered by the insolvency of reinsurers. Cummins and Weiss (2009) have argued that convergence of the financial services industry especially in insurance sector and capital markets is one of the most significant economic developments. The driving forces of this conversion are: reinsurance underwriting cycles, increased frequency and severity of catastrophic risks and advancement of computing and communication technologies. Such forces have led the development of financial instruments that contain the element of traditional reinsurance and financial contracts. Reinsurance markets undergo alternating periods of hard and soft markets. The period of hard market increases the difficulties of insurers' in risk management and cost prediction and creates market inefficiencies.

Cummins and Weiss (2011) have examined the reinsurance counterparty relationships by providing firm and aggregate level reinsurance information of both property-liability and life insurance companies of USA. They have argued that many of the direct insurers would be at great risk if several major reinsurers become insolvent due to the high concentration of ceded premium. Because of heavy dependence of property-casualty insurance industry on reinsurance, it is subject to systemic risk. Such risk increases with the complexity of reinsurance market. In insurance sector there can be significant systemic vulnerability because of interconnectedness of the sector and reinsurance spirals in which financial condition of multiple reinsurers deteriorates simultaneously because of complex retrocession transactions. 
The literature highlights that the reinsurance may positively affect the underwriting capacity of direct insurer but its consistent and more than required use may also increase the risk of bankruptcy.

Many incentive problems have been faced by the policyholders in the insurance market. Such incentive problems arise due to alteration on various aspect of the firm's underwriting policies, investment and its dividend policies by the shareholders after issuing the insurance policies. The shareholders do such alteration because they want to affect the wealth transfers that are occurred between the policyholders and themselves. So, the price paid by the policyholders may be affected due to this expected behavior of shareholders and this reduced price can be treated as the agency cost. The magnitude of these agency costs will be high if the leverage level of firm is high. Because the increased level of leverage increases the default probability of the firm. The purchase of reinsurance will reduce the leverage level of firm and also reduces these agency costs (Mayers \& Smith, 1990). Carson and Hoyt (1995) have shown that there is an optimal level of leverage which is beneficial for company and up to that level a firm increases its value but exceeding that level the firm will decrease its value. Chen, Hamwi, and Hudson (2001) have shown that purchase of reinsurance initially causes the leverage level of the firm to decrease but its consistent use increases such level and increases the risk of insolvency. Garven and Tennant (2003) have shown that the demand of reinsurance increases with the financial leverage and emphasized that the reinsurance can be considered as both financing decision and a risk management mechanism.

The reinsurance practice also benefited the policyholders, by way of reducing the load of high premiums on the policyholders which they have to pay for compensating the insurer's cost of bankruptcy due to large policies in the absence of reinsurance (Mayers \& Smith, 1981). Risk averse insurers use reinsurance to diversify and to decrease their risk but riskneutral insurers use reinsurance to increase the firm value. By using this practice the value of policies can be increased for policyholders because it reduces the insolvency or bankruptcy risk of direct insurer and act as the mechanism of risk diversification for policyholders (Hoerger, A. Sloan, \& Hassan, 1990). In order to achieve their solvency target the insurance companies have to increase their capitalization level by raising new capital or it can adopt the mechanism of risk transfer i.e., reinsurance (Garven \& Tennant, 2003).

The purchase of reinsurance is a capital structure decision. The insurers want to retain optimal level of underwriting risk which relates to their level of capitalization. In case of losses the liability of equity holders to pay losses is limited to the assets of the company. The remaining losses are unable to be paid by the company and the company has the option to declare its bankruptcy or insolvency (Cummins, Dionne, \& Nouira, 2008). All these points show that even though reinsurance enhances the capital and underwriting capacity, but if the direct insurer (without increasing its own capital) continues to write more business, the firm's leverage level will increase and resultantly, the profitability will decrease and the financial distress and probability of the bankruptcy will increase.

\section{Theoretical Framework}

The theory which explains the motives for an insurance company to purchase reinsurance is Corporate Demand Theory (CDT). The main motivation to purchase insurance or reinsurance

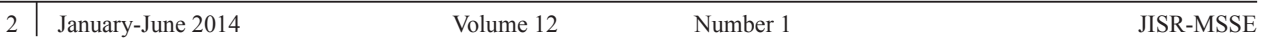


is risk sharing but the optimal risk sharing is not the only reason or motive for purchasing reinsurance (Plantin, 2006). Mayers and Smith (1990) have shown that the company's motive to buy insurance and insurance company's motive to buy reinsurance are quite similar, and have presented the reasonable basis of positive and negative facets of reinsurance. Figure 1 presents the relationship between reinsurance operations and firm's capital structure with the profitability of non-life insurance companies.

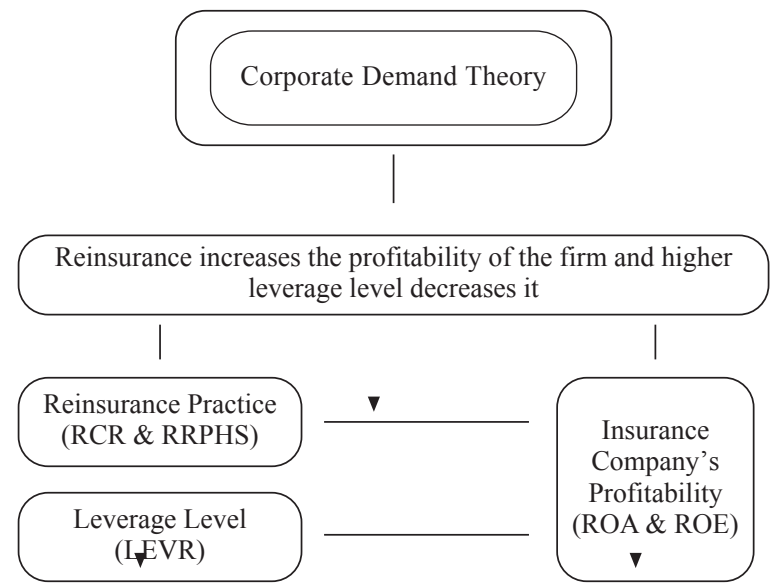

Figure 1: Connecting Figure of Corporate Demand Theory (CDT) and Variables

According to CDT reinsurance enhances the profitability and leverage level of the firm reduces it. Reinsurance reduces the risk of insolvency whereas higher leverage increases the risk of default. This shows the positive affect of reinsurance for direct insurer. This effect will be measured by analyzing the impact of reinsurance utilization (exposure) and firm's leverage ratio on the firm's profitability. Leverage Ratio (LEVR) is also called solvency ratio and shows the strength of an insurance company. This ratio also shows the underwriting capacity of the insurer. Following hypotheses have been framed to analyze the relationship of profitability with reinsurance utilization and exposure and leverage level:

H1॰: Reinsurance practice has a significant effect on the profitability of domestic non-life stock insurers in Pakistan

H1a: Reinsurance practice does not have a significant effect on the profitability of domestic non-life stock insurers in Pakistan

$\mathrm{H} 2 \circ$ : Leverage has a significant effect on the profitability of domestic non-life stock insurers in Pakistan

H2a: Leverage does not have a significant effect on the profitability of domestic non-life stock insurers in Pakistan

To test these hypotheses, random effect model (Eq. $1 \& 2$ ) is estimated for a panel of 22 insurance companies over a ten years time period. 


$$
\begin{aligned}
& R O A_{i t}=\gamma_{i}+\gamma_{11} R C R_{i t}+\gamma_{12} R R P H S_{i t}+\gamma_{13} L E V R_{i t}+\xi_{i t} \\
& R O E_{i t}=\gamma_{i}+\gamma_{21} R C R_{i t}+\gamma_{22} R R P H S_{i t}+\gamma_{23} L E V R_{i t}+\xi_{i t}
\end{aligned}
$$

In a panel setting equation. ( $1 \& 2$ ) may be viewed as a model where $\gamma_{i}=C_{O}+C_{i}$ is made up of a constant $\left(C_{O}\right)$ and an independent firm specific component $\left(C_{i}\right)$ that is assumed to be a realization of an iid (independently and identically distributed) random variable with distribution $\left[0,0^{2}\right]$. Eq. $(1 \& 2)$ should therefore be estimated as a random effect model. The variables are defined as follows:-

$$
\begin{array}{ll}
\text { ROAit } & =\text { Return on assets } \\
\text { ROEit } & =\text { Return on equity } \\
\text { LEVRit } & =\text { Leverage ratio } \\
\text { RCRit } & =\text { Ratio of ceded reinsurance } \\
\text { RRPHSit } & =\text { Ratio of reinsurance recoverable to policyholders' surplus } \\
\xi_{\text {it }} & =\text { White-noise error term }
\end{array}
$$

Variables and their theoretical justification is as under:

Profitability Ratios: Return on Assets (ROA) and Return on Equity (ROE) are the conventional profitability measures and have been extensively used in literature (Mohd., Abd., \& Chanta, 2005; Kozak, 2011; Hutchisan \& Cox, 2006; Al-Shami, 2008). Malik (2011), and Cummins, Feng, and Weiss (2011) have used ROA and ROE in their analysis in order to find the relationship between firm performance and reinsurance utilization, exposure and concentration. They found that firm performance is positively related to reinsurance utilization and exposure while it is adversely related to reinsurance concentration. The formulas for the ratios are as follows:

$$
\begin{aligned}
& \mathrm{ROA}=(\text { Profit after Taxes }(\mathrm{PAT}) / \text { Total Assets }) \\
& \mathrm{ROE}=(\text { Profit after Taxes }(\text { PAT) } / \text { Shareholders' Equity })
\end{aligned}
$$

Leverage Ratio: Leverage ratio (NPW to PHS) is the most frequently used measure of financial soundness and strength of an insurance company. It is a leverage ratio and also called solvency ratio. It implies that "how much risk is being retained by an insurance company relative to the financial resources available to it." National Association of Insurance Commissioners (NAIC) considers this ratio over 2:1 to be very dangerous for commercial companies (TRACS, 2010). Chen, Hamwi, and Hudson (2001) have used leverage ratio in their analysis in order to find the relationship between the firms' leverage level and risk of insolvency and found significant positive relationship which implies that with the increase in the leverage level of firm the risk of insolvency increases. Cummins, Feng, and Weiss (2011) have used leverage ratio in their study as independent variable to see the relationship between reinsurance utilization and exposure and firms' leverage ratio and found significant positive relationship. And conclude that the firms which are highly levered demand reinsurance more so that they can decrease their leverage level and can write more business without increasing their capital. Shiu (2011) has also used leverage ratio in his study to see the impact of leverage on ceded reinsurance and found same results.

Reinsurance Utilization and Exposure Ratios: Ratio of ceded reinsurance (RCR) and Ratio of reinsurance recoverable to policyholders' surplus (RRPHS) are the long-established and conventional reinsurance measures. RCR gives direct information about the volume and

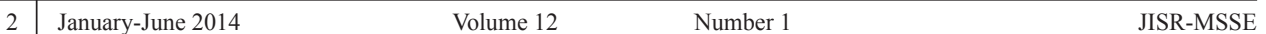


magnitude of reinsurance transactions that take place between the parties i.e. insurer and reinsurer. Mayers and Smith (1990), Chen, Hamwi, and Hudson (2001), Cole and McCullough (2006), Powell and Sommer (2007), Cummins, Dionne, and Nouira (2008), and Cummins, Feng, and Weiss (2011) have used these ratios in their analysis as the measure of reinsurance utilization. Smith (2011) has asserted that RRPHS is the gauge of dependence of an insurer on its reinsurers and give an idea about the potential and possible exposure to the collectability problems of reinsurance. Cummins, Feng, and Weiss (2011) have used this ratio in their research so as to get the relationship between firm performance and reinsurance dependence and exposure. The formulas for calculation of these ratios are as follows:

$$
\begin{aligned}
& \mathrm{RCR}=(\text { Reinsurance Ceded }(\mathrm{RC}) / \text { Net Premium Written }(\mathrm{NPW})) \\
& \text { RRPHS }=(\text { Ceded Reinsurance Recoverable }(\mathrm{CRR})+\text { Ceded unearned Premium } \\
& (\mathrm{CUP})+\text { Ceded Commission }(\mathrm{CC})) / \text { Policyholders' Surplus (PHS) }
\end{aligned}
$$

\section{Data, Estimation and Interpretation of the Results}

Secondary data is used for analysis. Data is authentic because it is collected from the audited Financial Statements of insurance companies under the "Pakistan Generally Accepted Accounting Principles (GAAP)" and hence offers the most pragmatic view of the insurance companies. Data is gathered from the websites of insurers, from the Insurance Year Books issued by "Insurance Association of Pakistan" and from "Lahore Stock Exchange". The population encompasses all the "private sector domestic non-life stock insurers" which are presently active in Pakistan. As there are not a very large number of such insurers so all the companies established before 2001 are included in this article, except those which are engaged in insuring specific areas. According to the list provided by SECP there are total 31 companies and from them 5 companies are established after 2001 and 2 companies only insure specific areas, from remaining 24 companies 2 companies are eliminated because of non-availability of data. Therefore, the final sample comprises 22 companies. The list of sample companies is attached in Appendix.

Table 1 shows the descriptive statistics of all the variables from all the domestic non-life stock insurers currently operating in the private sector of Pakistan, for the period of ten years from 2002 to 2011. Central Insurance Company Limited has the highest average ROA i.e., 0.391. Similarly, it also has the second highest ROE which is 0.495 . The firm also shows higher values higher values of standard deviation for ROA and ROE i.e. 0.508 and 0.659 respectively. The mean values of ROA for all the companies have been presented in descending order. Central Insurance Company Limited also has maximum mean value of RCR i.e., 0.755. The leverage ratio of this company is quite low i.e., 0.233. All these financial indicators indicate that company is financially stable, so it can afford this high ratio of ceded reinsurance, because now ceding reinsurance not only allow the company to increase its business without increasing its capital but also lower its leverage level by reducing its NPW.

Shaheen Insurance Company Limited has maximum mean value of LEVR i.e., 2.485 which is not good for the company. High leverage ratio signifies high risk of insolvency and financial distress of the company. Although ceding reinsurance reduces the leverage level of the firm but it happens up to some extent exceeding that extent ceding reinsurance increases the leverage level of the firm. IGI Insurance Company Limited has minimum mean value of LEVR i.e., 0.120 which shows that the company is financially stable and has lesser risk of insolvency. 
Table 2: Descriptive Statistics of the Study Variables.

\begin{tabular}{|c|c|c|c|c|c|c|c|c|c|c|}
\hline \multirow[t]{2}{*}{ Insurance Companies } & \multicolumn{2}{|c|}{ ROA } & \multicolumn{2}{|c|}{ ROE } & \multicolumn{2}{|c|}{ LEVR } & \multicolumn{2}{|c|}{ RCR } & \multicolumn{2}{|c|}{ RRPHS } \\
\hline & Mean & S.D. & Mean & S.D. & Mean & S.D. & Mean & S.D. & Mean & S.D. \\
\hline Central Insurance Co. Ltd. & 0.391 & & & & & & & & & 0.072 \\
\hline Adamjee Insurance Co. Ltd. & 0.284 & 688 & 0.750 & 672 & 411 & .781 & .345 & 055 & 556 & 411 \\
\hline IGI Insurance Co. Ltd. & 163 & 210 & 0.236 & 262 & 0.121 & 087 & 506 & 075 & 159 & 138 \\
\hline Habib Insurance Co. Ltd. & 123 & .170 & 0.232 & .321 & 0.404 & 0.387 & .478 & 0.019 & .376 & .399 \\
\hline Atlas Insurance Co. Ltd. & .121 & 0.134 & 0.289 & 0.261 & 0.621 & 0.246 & 0.592 & 0.274 & 0.519 & 0.361 \\
\hline \multicolumn{11}{|l|}{ The United Insurance } \\
\hline Company of Pakistan Lt & & .046 & .167 & .085 & 0.757 & 0.21 & 0.289 & 0.112 & 0.328 & 0.087 \\
\hline $\mathrm{C}$ & 0 & 96 & .205 & & & & & & & 0.315 \\
\hline e Co. I & & & & & & & & & & 0.422 \\
\hline 1. Insurance Co. Ltd. & & & & & & & & & & 0.384 \\
\hline Ltd. & & & & & & & & & & 079 \\
\hline & & & & & & & & & & 109 \\
\hline & & & & & & & & & & .297 \\
\hline & 2 & 204 & 0.226 & & 478 & 2.3 & 402 & & 0.683 & 0.603 \\
\hline New Jubilee Insurance Co. Ltd. & 0.038 & 0.239 & 0.245 & 0.157 & 0.713 & 0.529 & 0.439 & 0.062 & 0.56 & 0.833 \\
\hline \multicolumn{11}{|l|}{ The Pakistan General Insuran } \\
\hline & 038 & 047 & 0.066 & 0.074 & 0.293 & 0.047 & 0.516 & & 0.328 & 0.115 \\
\hline & 035 & .026 & 0.137 & .106 & 1.327 & 2.84 & 318 & 0.106 & 0.746 & 0.32 \\
\hline & 032 & .055 & 0.074 & 0.114 & 0.371 & 0.166 & .453 & 71 & 0.398 & 0.217 \\
\hline C $\mathrm{Cotd}$ & 027 & .056 & 0.092 & 0.200 & 2.485 & 0.756 & .243 & 0.074 & 0.75 & 0.371 \\
\hline Insurance Co. Ltd. & 0.017 & 0.039 & 0.063 & 0.176 & 1.539 & 0.64 & 378 & & 965 & 0.387 \\
\hline & 017 & & 0.033 & 0.054 & 0.206 & 0.113 & 0.397 & 0.054 & 0.222 & 0.126 \\
\hline The Crescent Star Insurance Co. Ltd. & 0.010 & 0.080 & 0.011 & 0.209 & 0.898 & 0.264 & 0.331 & 0.055 & 0.418 & 0.074 \\
\hline East West Insurance Co. Ltd. & 0.005 & 0.306 & -0.017 & 0.586 & 1.016 & 0.302 & 0.333 & 0.064 & 0.577 & 0.429 \\
\hline
\end{tabular}

Note: The companies have been presented in the descending order as per the mean value of the return on assets.

The universal Insurance Company Limited has maximum mean value of RRPHS i.e., 0.964. This ratio shows the dependence of an insurer on reinsurer and also shows the potential exposure of collectability problems from reinsurer. This ratio is quite high which is not in the favor of company but it is within the acceptable range i.e., $50 \%$ to $150 \%$ (Smith, 2011). Its leverage ratio i.e., 1.539 is also quite high. These characteristics show that company is financially unsound and is exposed to high risk of being insolvent. In this case the company should take proper measures to stabilize its financial position such as it should try to increase its capital and should try to reduce its dependence on reinsurers. The greatest variability or standard deviation is found in leverage ratio of Askari Insurance Company Limited i.e., 2.843 and minimum standard deviation is found in RCR of Habib Insurance Company Limited i.e., 0.019 .

This study has opted for one dependent variable and three independent variables. Random Effect Model (REM) is used for panel data regression analysis. Carneiro and Sherris (2005), Scordis and Barrese (2007), Garven and Grace (2007), and Cummins, Feng, \& Weiss (2011) have used such model for panel data analysis in their research. The results of the model (see table 2) show that RCR has significant positive relationship with ROA \& ROE and RRPHS has significant negative relationship with ROA \& ROE. The LEVR also has a significant negative impact on the firm's profitability. The values of R-square indicate that $64 \%$ of the variations in ROA are explained by RCR, RRPHS and LEVG and $46 \%$ of variations in ROE. The values of $\mathrm{F}$ statistics are significant at $1 \%$ which shows that the models are good fit.

\begin{tabular}{l|llll}
\hline 2 & January-June 2014 & Volume 12 & Number 1
\end{tabular} 
Table 3: Results of Random Effect Model (REM)

$\begin{array}{llll}\text { Model 1: } & R O E_{i t}=\gamma_{i}+\gamma_{11} R C R_{i t}+\gamma_{12} R R P H S_{i t}+\gamma_{13} L E V R_{i t}+\xi_{i t} R O A_{i t} \\ \text { Constant } & 1.1207^{*} & & \\ & (0.0002) & \text { F-statistic } & 6.8261^{*} \\ \text { RCR } & 0.9981^{*} & & (0.000) \\ & (0.0029) & \text { No. of observations } & 880 \\ \text { RRPHS } & -0.1339^{*} & & \\ & (0.0010) & \text { Akaike info criterion } & 2.8075 \\ \text { LEVR } & -0.2563^{* *} & \text { Schwarz criterion } & 3.1778 \\ & (0.0362) & \text { Durbin-Watson stat } & 1.9712 \\ \text { R-squared (Adj. R-sq.) } & 0.6448(0.5998) & & \end{array}$

Model 2: $R O E_{i t}=\gamma_{i}+\gamma_{11} R C R_{i t}+\gamma_{12} R R P H S_{i t}+\gamma_{13} L E V R_{i t}+\xi_{i t}$

\begin{tabular}{llll} 
Constant & $1.0026^{*}$ & F-statistic & $5.7132^{*}$ \\
& $(0.0016)$ & & $(0.000)$ \\
RCR & $0.8961^{*}$ & & 880 \\
& $(0.0087)$ & No. of observations & 2.2746 \\
RRPHS & $-0.11968^{*}$ & & 2.9789 \\
& $(0.0076)$ & Akaike info criterion & 1.6462 \\
LEVR & $-0.1762^{*}$ & Schwarz criterion & \\
& $(0.0489)$ & Durbin-Watson stat & \\
R-squared (Adj. R-sq.) & $0.4638(0.4319)$ & . & \\
\hline
\end{tabular}

Note: Values in parentheses denote the $\mathrm{p}$ values. The $1 \%$ and $5 \%$ level of significance is indicated by '*', '**', respectively

The results signify that RCR, RRPHS and LEVG have significant effect on ROA and ROE. So we can not reject both null hypotheses and conclusion can be made that reinsurance and capital structure have significant affect on the firm's profitability of the domestic non-life stock insurers currently operating in the private sector of Pakistan. The results are consistent with the previous studies. Existing literature indicates that use of reinsurance increases the profitability of the firm and hence reduces the risk of insolvency (Chen, Hamwi, \& Hudson, 2001; Garven \& Tennant, 2003; Cole \& McCullough, 2006; Powell \& Sommer, 2006; Cummins, Dionne, \& Nouira, 2008).

\section{Conclusion}

Insurance companies underwrite the risk of other companies but to mitigate their own risk, these insurance companies use reinsurance. The paper empirically examines the impact of reinsurance and leverage level of insurance companies on profitability in Pakistan using data for the period 2001 to 2010 . The estimated results support many of the findings of previous research in this area. In particular, reinsurance has a significant positive impact on profitability. It suggests the presence of large benefits associated with reinsurance utilization. Results also indicate that increased dependence on reinsurer will decrease profitability as leverage level has a significant negative impact on the profitability. The descriptive results show that most of the companies are financially stable, so such companies should take advantage of this practice by utilizing it within the solvency requirements in order to increase their underwriting 
capacity and to decrease their risk of insolvency. The companies which are financially unsound should try to increase their reinsurance for writing more business because continued ceding of business without increasing the capital will increase their risk of insolvency. So the companies whether financially stable or unstable should try to reduce their dependence and exposure of reinsurance.

\section{References}

Archer, S., Karim, R. A., and Nienhaus, V. (2009). Takaful Islamic Insurance: Concepts and Regulatory Issues. John Wiely and Sons (Asia) Ptv. Ltd.

Arndt, D., Bartenstein, C., Brohm, A., Knott, M., Mai, G., Raudmann, D. N., et al. (2004). Reinsurance Principles and Stated of the Art (2nd ed.). Verlag Versicherungswirtschaft Gmbh, Karlsruhe.

Baur, P., and Donoghue, A. B. (2004). Understanding reinsurance: How reinsurence creates value and manage risk. Retrieved from www.grahambishop.com/documents store

Carneiro, L. A., \& Sherris, M. (2005). Demand for reinsurance: Evidence from Australian insurers. working paper, School of Acturial Studies, University of New South Wales.

Carson, J. M., \& Hoyt, R. E. (1995). Life insurer financial distress: classification models and empirical evidence. Journal of Risk and Insurance, 764-775.

Chen, Y., Hamwi, I. S., \& Hudson, T. (2001). The Effect of Ceded Reinsurance on the Solvency of Primary Insurers. International Advances in Economic Research, 7(1), 66-67.

Clark, D. R. (2005). Reinsurance Applications for the RMK Framework. In CAS Forum, 353-366.

Cole, C. R., \& McCullough, K. A. (2006). A Reexamination of the Corporate Demand for Reinsurance. Journal of Risk and Insurance, 73(1), 169-192.

Cummins, J. D., \& Song, Q. F. (2008). Hedge the hedgers: usage of reinsurance and derivatives by PC insurance companies. Working Paper, Wharton School, University of Pennsylvania, Philadelphia.

Cummins, J. D., \& Weiss, M. A. (2009). Convergence of lnsurance and financial markets: hybrid and securitized risk-transfer solutions. Journal of Risk and Insurance, 76(3), 493-545.

Cummins, J. D., \& Weiss, M. A. (2014). Systemic Risk and the US Insurance Sector. Journal of Risk and Insurance, 81(3), 489-528.

\begin{tabular}{l|llll}
\hline 2 & January-June 2014 & Volume 12 & Number 1
\end{tabular} 
Cummins, J. D., \& Weiss, M. A. (2000). The global market for reinsurance: Consolidation, capacity, and efficiency. Brookings-Wharton Papers on Financial Services, 3, 159209.

Cummins, J. D., Feng, Z., \& Weiss, M. A. (2011). Reinsurance counterparty relationships and firm performance in the US property-liability insurance industry. Working Paper, Temple University.

Cummins, J., Dionne, G., \& Nouira, R. G. (2008). The cost and benefits of reinsurance. Centre Interuniversitaire De Recherche Sur Les Reseaux d Entreprise, La Logistique et le Transport CIRRELT .

Garven, J. R., \& Grace, M. F. (2007). Adverse selection in reinsurance markets. Working Paper.

Garven, J. R., Tennant, J. L., Consultants, G. R. C., Center, F., \& Street, E. M. (2003). The demand for reinsurance: Theory and empirical tests. Insurance and Risk Management, 71(2), 217-238

Gujarati, D. N. (2012). Basic Econometrics. Tata McGraw-Hill Education.

Hoerger, T. J., Sloan, F. A., \& Hassan, M. (1990). Loss volatility, bankruptcy, and the demand for reinsurance. Journal of Risk and Uncertainty, 3(3), 221-245.

Krvavych, Y., \& Sherris, M. (2004) Enhancing insurer value through reinsurance optimization in the presence of frictional costs. Actuarial Studies, Faculty of Commerce and Economics, University of New South Wales.(nd).

Mayers, D., \& Smith, C. W. (1981). Contractual provisions, organizational structure and conflict control in insurance market. The Journal of Business, 54 (3), 407-434.

Mayers, D., \& Smith, C. W. (1990). On the Corporate Demand for Insurance: Evidence form the Reinsurance Marke. The Journal of Business, 63, 19-40.

Pitselis, G. (2008). An overview on solvency supervision, regulations and prediction of insolvency. Belgian Actuarial Bulletin, 8 (1), 37-53.

Plantin, G. (2006). Does reinsurance need reinsurance? The Journal of Risk and Insurance, 73 (1), 153-168.

Powell, L. S., \& Sommer, D. W. (2007). Internal versus external capital markets in the insurance industry: the role of reinsurance. Journal of Financial Services Research, 31(2-3), 173-188.

SBP, S. B. (2003). Publications on Financial Sector Assessment, Review of Insurance Industry. State Bank of Pakistan. 
Scordis, N., and Barrese, J. (2007). The Economic Value from the use of Reinsurance. American Rsk and Insurance Association (ARIA) .

SECP. (2011). Insurance Ordinance 2000 (Amended upto Nov. 2011). Securities and Exchange Commissiono f Pakistan, Insurance Division.

Swiss, R. (2002). Introduction to Reinsurance. Swiss Reinsurance Company, Technical Training and Chief Underwriting Office.

Swiss, R. (2009). Natural Catastrophes and Man-Made disasters Sigma No. 2. Economic Research and Consulting .

Swiss, R. (2003). Reinsurance-A Systematic Risk? Sigma, No. 5. Swiss Reinsurance Company Economic Research and Consulting.

Shiu, Y. M. (2011). Reinsurance and Capital Structure: Evidence From the United Kingdom Non?Life Insurance Industry. Journal of Risk and Insurance, 78(2), 475-494.

Smith, J. (2011). Best's Key Rating Guide. A.M. Best Publications, A.M. Best Company. TRACS. (2010). Towers Watson Recognized and Accepted Captive Standards. 


\section{Appendix}

Table 1: The list companies taken for the analysis.

\begin{tabular}{cl}
\hline Serial No. & Insurance Companies \\
1 & Adamjee Insurance Company Limited \\
2 & Alpha Insurance Company Limited \\
3 & Asia Insurance Company Limited \\
4 & Askari General Insurance Company Limited \\
5 & Atlas Insurance Company Limited \\
6 & Capital Insurance Company Limited \\
7 & Central Insurance Company Limited \\
8 & Century Insurance Company Limited \\
9 & East West Insurance Company Limited \\
10 & EFU General Insurance Company Limited. \\
11 & Habib Insurance Company Limited \\
12 & IGI Insurance Company Limited \\
13 & New Jubilee Insurance Company Limited \\
14 & Premier Insurance Company Limited \\
15 & Reliance Insurance Company Limited \\
16 & Security General. Insurance Company Limited \\
17 & Shaheen Insurance Company Limited \\
18 & Silver Star Insurance Company Limited \\
19 & The Crescent Star Insurance Company Limited \\
20 & The Pakistan General Insurance Company Limited \\
21 & The United Insurance Company of Pakistan Limited \\
22 & The Universal Insurance Company Limited \\
\hline
\end{tabular}

